\title{
BIOCLIMATIC STRATEGIES FOR THE CITY OF LAJEADO/RS-BRAZIL, USING DATA ANALYSIS OF REGIONAL CLIMATE
}

\author{
SPINELLI, Rodrigo - rspinelli@univates.br \\ Universidade do Vale do Taquari/UNIVATES
}

KONRAD, Odorico - okonrad@univates.br

Universidade do Vale do Taquari/UNIVATES

\author{
CAMBEIRO, Faustino Patiño - faustinopc@gmail.com \\ Universidade de Vigo/Espanha
}

AHLERT,Edson- edsonahlert@univates.br

Universidade do Vale do Taquari/UNIVATES

\author{
SPINELLI, Fabiana Braun - fabib74@gmail.com \\ Bacharel Arquitetura e Urbanismo/UNISINOS
}

\section{QUADROS, Eric Augusto - equadros1@universo.univates.br Universidade do Vale do Taquari/UNIVATES}

\begin{abstract}
The city of Lajeado is located at the Vale do Taquari region, $120 \mathrm{~km}$ away from Porto Alegre, the capital of Rio Grande do Sul (RS) state, Brazil. Locally, the civil construction industry has grown $517.7 \%$ between the years of 1991 and 2011 . Basic information concerning the choice of materials suitable to the climate, and early studies focused on the research of natural ventilation, are denied in the development of projects of buildings. Bioclimatic Charts are being developed for Brazil, in which architectural strategies can be determined for application in building project design. The study here shown is about acquisition of climate data for the city of Lajeado in southern of Brazil, during the period of 2004 to 2015, including data processing and analysis using BioEstat statistic software and data plotting to the bioclimatic chart with the use of the Sol-ar software. The results show how building design strategies like passive solar heating and thermal inertia, as well as an adequate application of construction materials, must be used more, as to working with thermal isolation in cold and hot days.
\end{abstract}

Keywords: Bioclimatology; Bioclimatic Charts; Wind Charts; Architectonic Strategies; Energy Efficiency;

ESTRATÉGIAS BIOCLIMÁTICAS PARA A CIDADE DE LAJEADO/RS-BRASIL, A PARTIR DA ANÁLISE DE DADOS CLIMÁTICOS REGIONAIS

RESUMO: A cidade de Lajeado/RS-Brasil está localizada no Vale do Taquari, distante a 120 quilômetros de Porto Alegre, capital do estado do Rio Grande do Sul (RS). Localmente, o setor da construção civil apresentou um crescimento de $517,7 \%$ entre os anos de 1991 e 2011. Informações básicas relacionadas a escolha de materialidade adequada ao clima, e estudos iniciais voltados a pesquisa de ventilação natural, são negados no desenvolvimento de projetos de edificações. Para o Brasil, se trabalha com o desenvolvimento da Carta Bioclimática, em que se definem estratégias arquitetônicas a serem aplicadas no desenvolvimento de projetos. O estudo apresentado neste artigo, faz - levantamento de dados climáticos para a cidade de Lajeado/RS-Brasil no período de 2004 a 2015, em que foram planilhados, analisa no software estatísticos BioEstat, e com a utilização do software Sol-ar, plotados na Carta Bioclimática. Os resultados apresentam como estratégias que devem ser mais utilizadas nas edificações, o aquecimento solar passivo, e a estratégia de inércia térmica, aplicando de forma adequada os materiais, para se trabalhar com isolamento térmico, tanto para dias frios e quentes. 
Palavras-chaves: Bioclimatologia; Carta Bioclimática; Carta de Ventos; Estratégias Arquitetônicas; Eficiência Energética;

\section{INTRODUCTION}

The energy crisis triggered in the early 1970s has shown a reality in which it has become fundamental to work with architectural strategies, which are targeted to minimize the energy consume and indicate rationalization of comfort methods and strategies for the use of natural resources (SPINELLI; ALVES; KONRAD, 2013).

The climatic alerts were intensified "with the foundation of the Club of Rome and the conference of Stockholm in Sweden in 1972, where amongst other environmental themes, the concept of sustainable development was presented, advocating for the moderate use of natural resources as being finite, as well as to be concerned in terms of the susceptibility of some natural environments" (MUNIZ; CARACRISTI, 2015).

From the execution phase to the period of use of buildings, the impacts of buildings to the natural environment regarding $\mathrm{CO} 2$ emissions are responsible for "more than half of all emissions causing climatic change" (ROAF et al., 2009, p. 22). Other alarming data point out that the civil engineering market uses approximately $40 \%$ of the non-renewable natural resources of the planet (JOURDA, 2012).

The Directive 2002/91/EC of the European Parliament and Council, concerning on the Energy Performance of Buildings (2002), determined that the construction materials have to be used in a rational way, thus, the buildings must be energetically efficient as to minimize the emission of global warming gases. The article 8 determines as follows: "The Directive 89/106/EEC of the Council from December 21, 1988, determines the approximation of laws, regulations and administrative provisions of the Member States relating to the construction products, which requires that the construction works and their heating, cooling and ventilation installations must be designed and built in such a way that the amount of energy required in use shall be low, when considered the location climatic conditions and occupants".

In November 2016 the Paris Agreement will come into force with the aim of considerably reducing the emission of greenhouse gases, to limit the expansion of the average global warming which has raised to alarming levels (ONU; 2016). According to the UN, "2015 was the hottest year of the modern world and in the first six months of 2016, until now, all previous records were broken".

This leads to an observation of the human being among nature, analyzing its disconnection to the natural environment, in which, one see itself disconnected (capitalistic thinking, where one is only an exploiter), entailing one to recognize that a connection of the non-human nature to the human being, in a philosophic perspective, bring man to bethink his place and that of all living creatures in nature (SOFFIATI, 2008).

In this context, the sensibility for thermal comfort and the search for the best way to conform it to the use of buildings, pointing to the physical well- 
being has become more frequent in the last decades (LAMBERTS; XAVIER, 2003).

Ascenso (2015) presented a strategy developed by the European Union. Until the year 2020, all new buildings shall be energetically efficient, showing an energy balance of nearly zero, by consuming the same energy quantity it is capable to produce, imposing for every member state to develop the best method to achieve these aims and present them as a fundamental factor for climatic adaptation of buildings.

At the Third International Conference on Sustainable Future for Human Security (SUSTAIN 2012), which took place in Kyoto, Larasati ZR (2013) describes how the user comfort is fundamental as a parameter for the bioclimatic project, along with project parameters as: 1) use of landscape elements (plants, water, and so on); 2) construction according to solar orientation; 3) adequacy of the construction materials; 4) formal composition of the appropriate project; 5) project with solar protection; and 6) design of windows and facades for exploitation of natural ventilation. With these strategies, it is possible to consider a building low cost operation and maintenance.

According to the ASHRAE (American Society of Heating, Refrigeration and Air Conditioning Engineers), one definition of thermal comfort is: "the condition of mind, that reflects satisfaction of the individual with the thermal environment in which one is located", when the human person feels itself in a state of neutrality in relation to its environment (ASHRAE Standard 55, 1992 in ASHRAE, 2001).

The absence of neutrality in environmental comfort sensibility causes a drop in performance of work, physical, cognitive and learning activities, influenced by variations of the environmental temperature (BATIZ et al., 2009).

\subsection{BIOCLIMATOLOGY}

According to Olgyay (1968), bioclimatology is the application of climaterelated studies to all living beings. The application of these studies to architecture results the concept of the bioclimatic project, seeking to adjust the architectural project to local climatic conditions as to achieve thermal comfort conditions (in LAMBERTS et al., 2013, p. 84). The developed Bioclimatic Chart of Olgyay relates the temperature variation $\left({ }^{\circ} \mathrm{C}\right)$ and relative humidity of the air (\%) to the sensibility comfort.

The studies of Givoni (1969) realized with projects in Israel, USA and Europe, in which the expectations of the intern temperature for the buildings were considered without the use of any air conditioning system; improved the chart of Olgyay and linked the bioclimatic chart to the application of building project strategies.

Thus, the most suitable bioclimatic strategies to a determined location can be represented in format of a bioclimatic chart (GIVONI, 1992), in which temperature data of dry and wet bulb, absolute humidity and relative humidity are plotted to a psychrometric chart (also known as Test Reference Year Chart TRY). 
In Brazil, the NBR 15220-3 (ABNT, 2005) shows recommendations for building coating elements, like maximal thermal transmittance of roofs and extern walls according to the definition of eight bioclimatic zones, which cover the whole Brazilian territory, presenting more extensive strategies for the obtainment of thermal comfort, but not acting specifically matching the climate of a certain place.

In his study, Bogo (1994) shows the Bioclimatic Chart for Brazil, including nine main comfort zones, related to more adequate building strategies to Brazilian climate circumstances (in LAMBERTS et al., 2013, p. 85), according to the Bioclimatic Chart shown in Picture 1. According to Lamberts et al. (2013) the comfort zones 7, 10, 11 and 12 are cited as "Strategy Intersection Zones"; for these cases, the overlapping strategies can be utilized separately or concurrently.

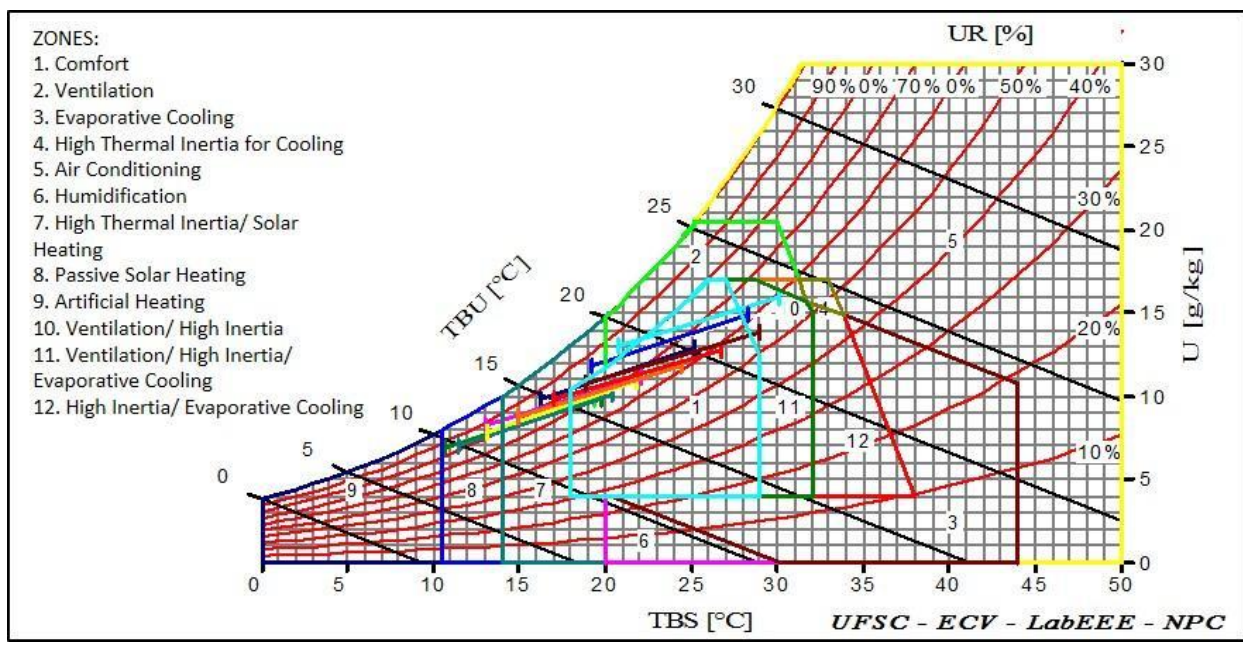

Picture 1 - Bioclimatic Chart for the city of Porto Alegre/RS-Brazil. Source: Software Analysis Bio 2.2, LabEEE - UFSC.

Relating to the data analysis for development of building energy simulation, Bhandari et al. (2012) describes, that "it would be ideal measuring meteorology data at the buildings site to capture relevant variations of the microclimate, but this is generally considered as a prohibitive cost", indicating thus to appropriate the necessary parameters for a development of the bioclimatic chart.

In a study, undertaken for the city of Caraguatatuba/SP, Brito and Cabral (2008) used data of the National Institute for Meteorology (INMET) from the period of 1998 to 2006, generating the bioclimatic charts for each year and, in doing so, developed a comparative analysis. As the result, Brito and Cabral verified an inadequacy of the local architecture and construction materials and indicated the use of comfort strategies which are cited to be adequate to the local climate. It was mentioned that for the buildings it was used air conditioning systems over a long annual period in an inadequate way, whereas this strategy in bioclimatic charts is pointed out just for $5 \%$ possibility of utilization in buildings, causing an elevated energy consume. 
Grigoletti et al. (2016) realized an additional study completing the existing Bioclimatic Chart for the city of Santa Maria/RS, generated with data of an eight-year period and revised it for a twelve-year period, ab initio of registered data obtained from the weather station of Santa Maria Air Base (Base Aérea de Santa Maria, BASM), and registered by INMET. The study highlights that in the developed revision, remained a predominance of presented strategies of the original Bioclimatic Chart.

The natural ventilation strategy is one of the constructive strategies in the bioclimatic chart (Zone 2). Lamberts et al. (2013) describes that the use of natural ventilation resource can be presented with the help of the "wind rose", in which will be plotted the data of predominant orientation (\%) and average wind speed $(\mathrm{m} / \mathrm{s})$. Thus, the analysis through the chart designer enables the selection for the best orientation and localization of the vents and openings, or specific elements for the capture of fresh breezes in the summer period or protection from colder winds in the winter period.

\subsection{CITY OF LAJEADO/RS-BRAZIL}

The city of Lajeado is located at the Vale do Taquari region, $120 \mathrm{~km}$ away from Porto Alegre, the capital of Rio Grande do Sul (RS) state, Brazil, as shown in Picture 2 (FEIL, 2009). Two of the municipal borders are contoured by Rio Forqueta (to the north), and Rio Taquari (to the east), both belonging to the Taquari-Antasm Hydrographic Basin, with a high water volume.

According to PML (2016) information, the local climate is classed as subtropical. Regarding geomorphology, the municipality is located at the "Geomorphological Araucárias Plateau Region (Serra Geral topography unit and Heights of Serra Geral topography unit)", with an average altitude of 65m (PML, 2016), in the transition range of morphological units called Depressão Central (altitudes close to 0) and the Northern Rio-Grandense Plateu (altitudes higher than $200 \mathrm{~m}$ ). Ao norte do município, a media de altitude amplia-se a $800 \mathrm{~m}$.
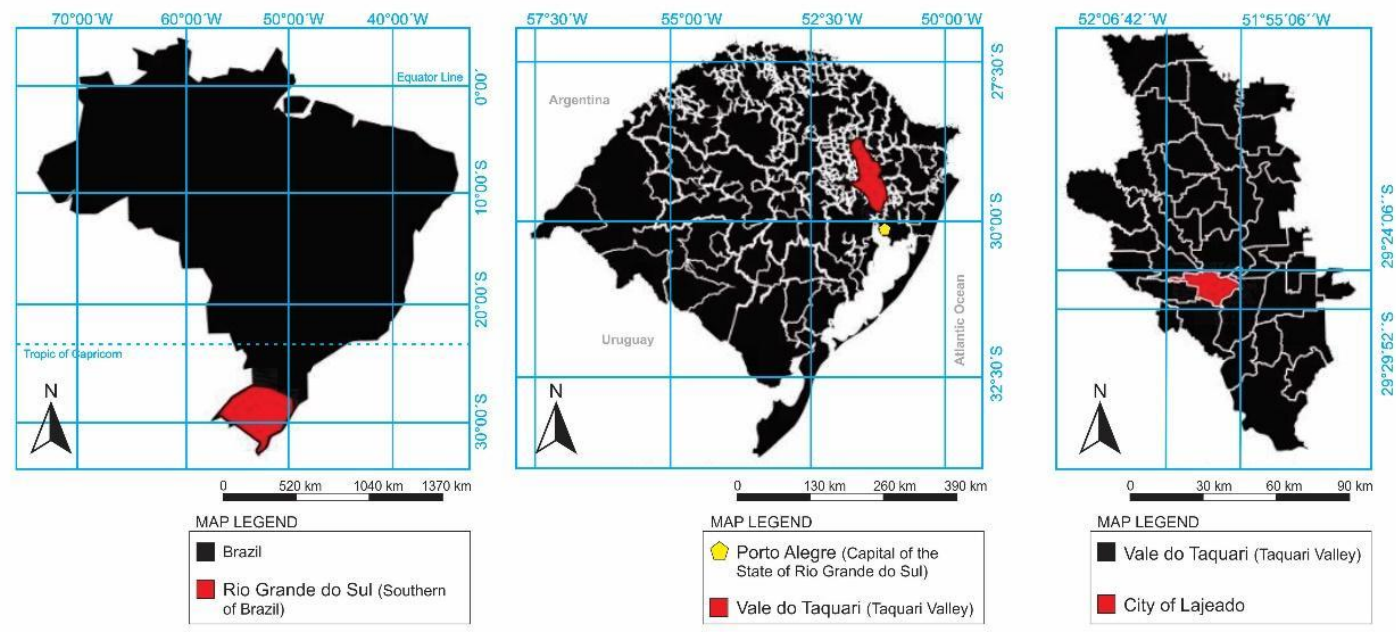

Picture 2 - Localization of the State Rio Grande do Sul in Brazil, of Vale do Taquari in the state Rio Grande do Sul, and the municipal area of Lajeado in Vale of Taquari. 
With a regard to buildings, the civil construction sector denoted an expansion of $517.7 \%$ between 1991 and 2011, according to data of the City Hall of Lajeado (Prefeitura Municipal de Lajeado, PML). This data highlight the strength of this sector within the local economy and underline the importance of the elaboration of designed building projects based on the analysis of local climatic data; a situation that not takes place. Basic information, like presented in NBR 15220-3, regarding the choice of adequate materials to the climate and initial studies concerning the natural ventilation research are denied in the development of these projects. The utilized standard materials in masonry is the massive ceramic brick with slabs made of a concrete and ceramics mixture, showing an elevated thermal transmittance value $(U)$ for the local climate (NBR 15220-3; 2005).

For the region where the city of Lajeado is located, Tomasini (2011) analyzed the wind patterns within the period covering the years 2003 to 2010, using collected data from the meteorological station of the Hydrometeorogical Information Center (Centro de Informação Hidrometeorológicas, CIH), localized at Universidade do Vale do Taquari - UNIVATES, and plotting the percentages to the wind rose, which resulted in a predominance of the winds NNW with $13.79 \%$ occurrence, ESE with $11.28 \%$, and NNE with $11.03 \%$.

The research data of Tomasini (2011) matches the data presented by the Wind Atlas of Rio Grande do Sul (2014), with resulting predominant wind directions for the region of the city Lajeado; with a predominance of directions NNE, N, LSE, SE and SSE. However, it should be noted that the studies from Tomasini and Wind Atlas do not indicate predominance percentages as well as develop any qualification of data in accordance to weather stations, and therefore limiting the use of the data by project planners.

Developing building design projects solely with information of natural ventilation would not lead to sufficient results regarding the thermal comfort and energy efficiency. Locally, a large number of developed projects do not take into account the regional climatic characteristics as much as materials definitions and elements, which allows a significant reduction of artificial conditioning system elements, widely used in annual periods with intense heat.

The studies carried out by Bhandari et al. (2012), Brito and Cabral (2008) and Grigoletti et al. (2016) support the need, for the city of Lajeado, of a development of tools to analyze constructive alternatives regarding the local climate, showing options for a more efficient construction of buildings.

A study developed by Gobo et al. (2015), analyzed data on urban level scale, based on the Methodology of Standard Years to determine the zoning of human thermal comfort to the state of Rio Grande do Sul, taking as basis the years 2002, 2004 and 2007. Shall be noted that for autumn and winter periods, the regional atmospheric dynamics is crucial to the uniformity comfort sensitivity (temperatures lower than the $13^{\circ} \mathrm{C}$ average- characterized as very cold), which covers the entire State (Picture 3 ).

During spring and summer, the distribution of thermal sensation tracks are related to the possible influence of climate controls, such as altitude, continentality, the maritime dimension and latitude of Rio Grande do Sul different regions. 


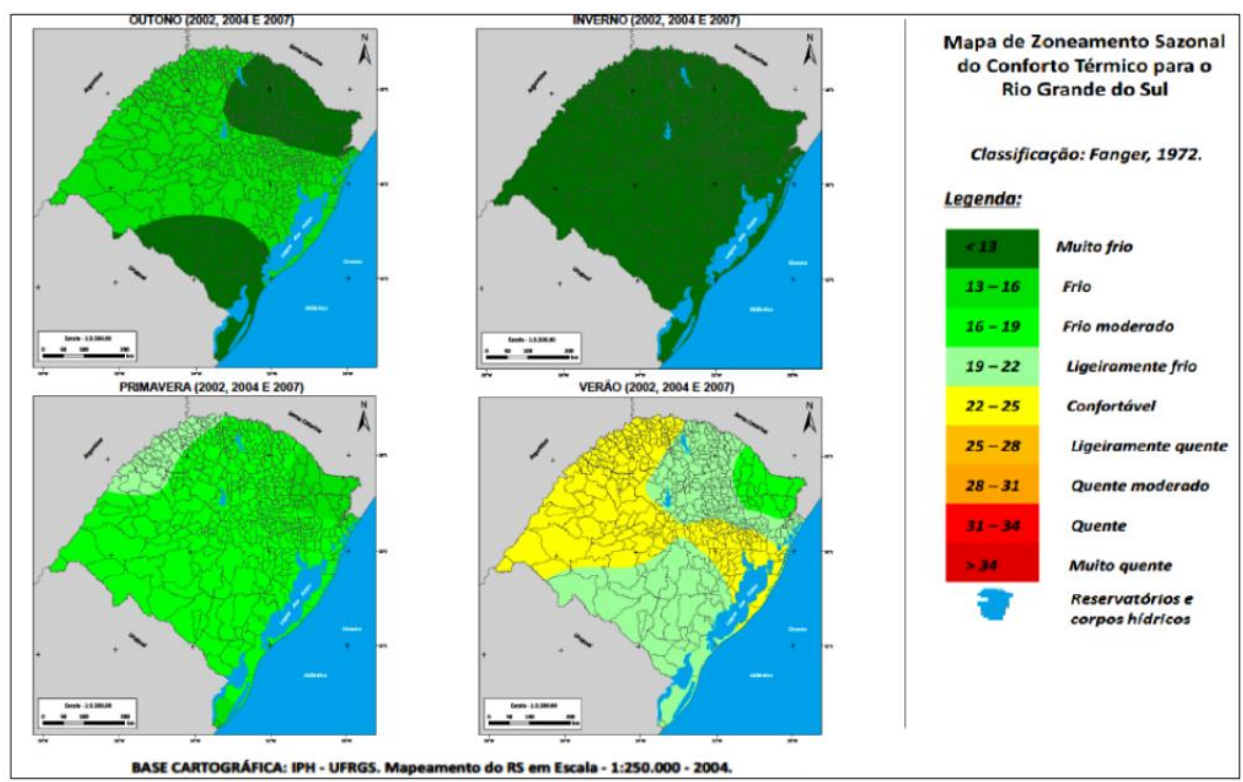

Picture 3 - Seasonal Zoning of thermal comfort for the Rio Grande do Sul. Source: GOBO et al. (2015, p. 467).

\subsection{OBJECTIVE}

The objective of this study is to perform a climatic data collection for the municipality of Lajeado in the period of 2004 to 2015, and to plot this data into the Bioclimatic Chart for Brazil. Furthermore, it will be made a data revision and qualification of the charts into climatic seasons including predominant wind speed and direction. Based on this information it will be possible to verify architectonic strategies that are more adequate for the adaption of projects to the local climate, allowing the energy efficiency analysis of buildings.

\section{METHODOLOGY}

For the development of the study, the whole data were collected at the $\mathrm{CIH}$, sampled by the weather station at the campus of the Universidade do Vale do Taquari - UNIVATES - Lajeado, whose geographic coordinates are latitude $29^{\circ} 29^{\prime} 13^{\prime \prime S}$ and longitude 51'59'50"W, with an altitude of 85 meters. The utilized weather station model is a wireless Vantage Pro 2, manufactured by Davis Instruments. It was measured the temperature, relative air humidity, atmospheric pressure, wind speed and direction $(\mathrm{km} / \mathrm{h})$, recording the data all the days during the duration of the project with intervals of 30 minutes (from 0:00 to 0:30 a.m., 1:00 to 1:30 a.m., and so on, thus completing $24 \mathrm{~h}$ ).

\subsection{DATA ANALYSIS}

All the collected data were tabulated into an electronic spreadsheet, giving the data for a minimum and maximum temperature range, the average temperature, and percentage for relative air humidity and atmospheric pressure initially for each day of the year, with the aid of pivot table data, which permits grouping and evaluation of the information. Subsequently, the monthly averages 
were calculated for every year, finalizing with calculation of the monthly averages of the analysis period, as presented in Table 1.

Table 1 - Climatic Data: monthly averages for the period (2004-2015).

\begin{tabular}{cccccc}
\hline & $\begin{array}{c}\text { AV.MAX. } \\
\text { TEMP. } \\
\left({ }^{\circ} \mathbf{C}\right)\end{array}$ & $\begin{array}{c}\text { AV.MIN. } \\
\text { TEMP. } \\
\left({ }^{\circ} \mathbf{C}\right)\end{array}$ & $\begin{array}{c}\text { AV. } \\
\text { TEMP. } \\
\left({ }^{\circ} \mathbf{C}\right)\end{array}$ & $\begin{array}{c}\text { AV. } \\
\text { HUMID. } \\
(\%)\end{array}$ & $\begin{array}{c}\text { AV. } \\
\text { PRESSURE } \\
(\mathbf{h P a})\end{array}$ \\
\hline JAN & 31.30 & 20.58 & 25.17 & 74.86 & 1008.70 \\
FEB & 31.20 & 20.83 & 25.01 & 75.06 & 1009.42 \\
MAR & 28.63 & 19.07 & 23.15 & 78.37 & 1011.22 \\
APR & 25.95 & 16.68 & 20.64 & 80.87 & 1013.34 \\
MAY & 21.73 & 13.63 & 17.64 & 84.01 & 1015.65 \\
JUN & 19.58 & 11.78 & 15.17 & 84.58 & 1016.72 \\
JUL & 19.23 & 10.31 & 14.41 & 81.37 & 1017.18 \\
AUG & 21.67 & 12.16 & 16.35 & 77.99 & 1016.11 \\
SEP & 22.68 & 13.70 & 17.42 & 78.84 & 1014.83 \\
OCT & 25.18 & 15.72 & 19.92 & 74.91 & 1011.80 \\
NOV & 27.91 & 17.47 & 22.31 & 73.92 & 1009.83 \\
DEC & 30.33 & 19.56 & 24.21 & 73.68 & 1008.31 \\
\hline
\end{tabular}

Source: the authors.

To confirm the significance of the monthly averages, every entry was analyzed using the statistical analysis software BioEstat ${ }^{1}$ (AYRES; 2007). Initially the monthly maximal average temperatures of the analyzed period (2004-2015) were inserted, and the statistical method for an Analysis of Variance (ANOVA) were applied with the criteria that the results present no significant variation ( $p$ less than one), referred to as calculated averages. Subsequently, the average minimum temperature, temperature, relative humidity and atmospheric pressure were treated as described above and the results obtained with the statistical analysis software was also applied with the same criteria as mentioned above.

To analyze the tabulated data for natural ventilation (direction and speed), an equation to count the number of incidences, where the wind occurred at a determined orientation (north, west, east, south, and so on) was applied, and also a separation of the enumeration for incidence by climatic seasons (summer, autumn, spring and winter) to boost the results of the wind chart. Then, the data for average wind speed separated by direction and climatic season was also developed applying the same procedure.

The obtained wind data was furthermore analyzed using the BioEstat software to develop the statistical analysis with application of Analysis of Variance with the criteria, which does not permit significant variation. With the validation of the data, the percentage of the average incidence of predominant

\footnotetext{
1 "BioEstat is especially aimed at graduation and post-graduation students, who can learn the basic concepts of statistics with it. The bundle of software is facilitated by the application itself and its instruction manual where the choice of an adequate test can be done in a practical way, according to the nature of data, number of samples and type of experimentation" (AYRES; 2007).
} 
Table 2 - Climate data: maximum and average absolute minimum temperature for the monthly period (2004-2015).

\begin{tabular}{cccccc}
\hline & $\begin{array}{c}\text { AV.AB. } \\
\text { MAX.TEMP }\end{array}$ & $\begin{array}{c}\text { AV.AB. } \\
\text { MIN.TEMP. } \\
\left({ }^{\circ} \mathbf{C}\right)\end{array}$ & $\begin{array}{c}\text { AV. TEMP. } \\
\left({ }^{\circ} \mathbf{C}\right)\end{array}$ & $\begin{array}{c}\text { AV. } \\
\text { HUMID. } \\
(\mathbf{\%})\end{array}$ & $\begin{array}{c}\text { AV. } \\
\text { PRESSURE } \\
(\mathbf{h P a})\end{array}$ \\
\hline JAN & 33.60 & 18.70 & 25.17 & 74.86 & 1008.70 \\
FEB & 33.80 & 18.40 & 25.01 & 75.06 & 1009.42 \\
MAR & 30.40 & 16.90 & 23.15 & 78.37 & 1011.22 \\
APR & 29.05 & 15.25 & 20.64 & 80.87 & 1013.34 \\
MAY & 24.80 & 11.40 & 17.64 & 84.01 & 1015.65 \\
JUN & 22.50 & 9.10 & 15.17 & 84.58 & 1016.72 \\
JUL & 22.80 & 5.85 & 14.41 & 81.37 & 1017.18 \\
AUG & 27.60 & 8.90 & 16.35 & 77.99 & 1016.11 \\
SEP & 26.25 & 11.10 & 17.42 & 78.84 & 1014.83 \\
OCT & 27.90 & 13.30 & 19.92 & 74.91 & 1011.80 \\
NOV & 29.90 & 14.50 & 22.31 & 73.92 & 1009.83 \\
DEC & 32.30 & 17.90 & 24.21 & 73.68 & 1008.31 \\
\hline
\end{tabular}

\section{RESULTS}

\subsection{BIOCLIMATIC CHART FOR LAJEADO/RS, FROM MONTHLY AVERAGE TEMPERATURES.}

The outcoming results from the data development process by the software was used to generate the Bioclimatic Chart for the city of Lajeado, as shown in Picture 5. It can be visually identified the application of defined strategies in the zones $1,2,7,8,9,10$ and 11 .

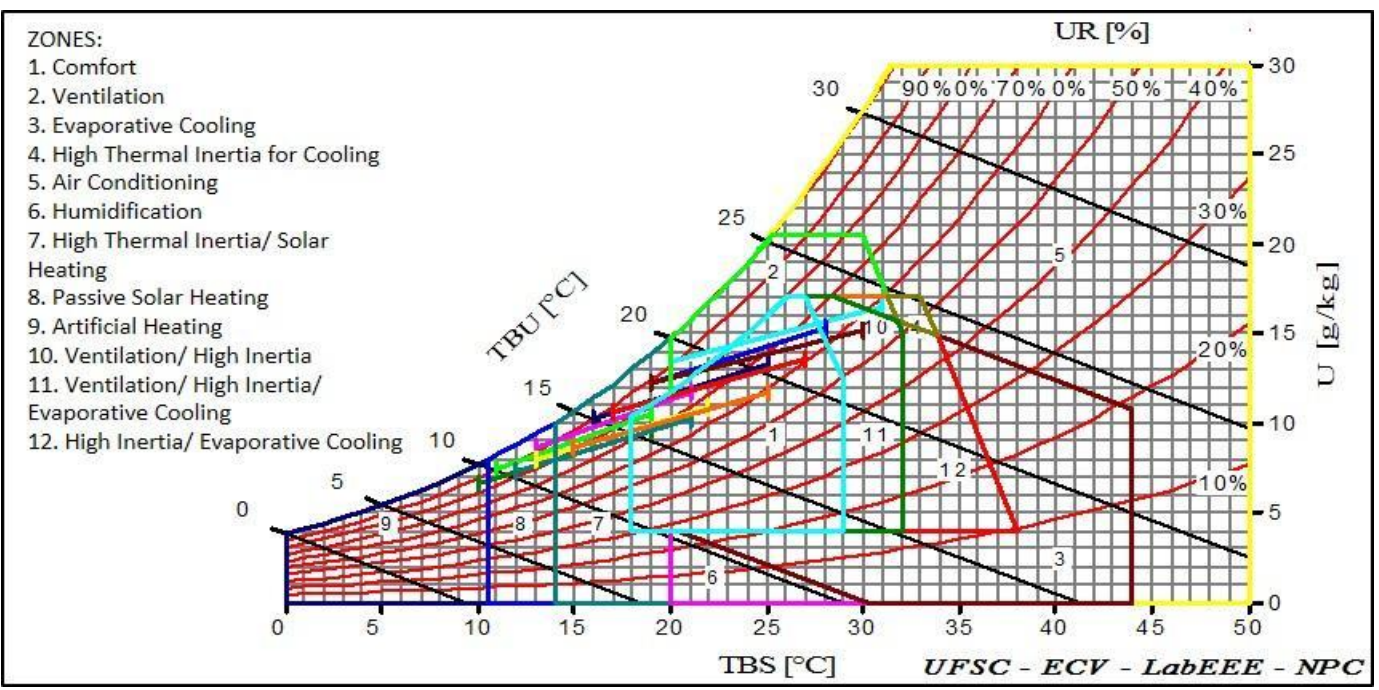

Picture 5 - Bioclimatic Chart for the city of Lajeado/RS (Annual Average). 
Hence, the data presented in the detailed report was transferred to the spreadsheet, shown in Table 3. For a better understanding, the data was expressed in percentage as number of days within each month, taking a sum of all relating values for each strategy. Totaling up the values resulted in the number of days (percent) each strategy should be used within the period of one year.

Table 3 - Monthly Bioclimatic Strategies for the city of Lajeado (Annual Average).

\begin{tabular}{cccccccc}
\hline & ZONE 1 & ZONE 2 & ZONE 7 & ZONE 8 & ZONE 9 & ZONE 10 & ZONE 11 \\
\hline JAN & $43.96 \%$ & $26.37 \%$ & & & & $2.91 \%$ & $26.78 \%$ \\
FEB & $40.15 \%$ & $29.44 \%$ & & & & $5.62 \%$ & $24.80 \%$ \\
MAR & $64.73 \%$ & $21.98 \%$ & $11.12 \%$ & & & $2.17 \%$ \\
APR & $60.22 \%$ & & $39.78 \%$ & & & & \\
MAY & $28.05 \%$ & & $59.45 \%$ & $12.51 \%$ & & & \\
JUN & $12.49 \%$ & & $50.01 \%$ & $37.50 \%$ & & & \\
JUL & $11.12 \%$ & & $44.44 \%$ & $38.89 \%$ & $5.56 \%$ & & \\
AUG & $33.34 \%$ & & $44.44 \%$ & $22.23 \%$ & & & \\
SEP & $44.45 \%$ & & $44.44 \%$ & $11.12 \%$ & & & \\
OCT & $70.00 \%$ & & $30.00 \%$ & & & & \\
NOV & $75.15 \%$ & & $24.86 \%$ & & & & \\
DEC & $59.63 \%$ & $13.55 \%$ & $9.10 \%$ & & & & \\
\hline
\end{tabular}

OBS.: Zone 1 - Thermal Comfort; Zone 2 - Natural Ventilation; Zone 7 - High Inertia / Passive Solar Heating; Zone 8 - Passive Solar Heating; Zone 9 - Artificial Heating; Zone 10 - Natural Ventilation / High Inertia; Zone 11 - Natural Ventilation / High Inertia / Evaporative Cooling.

Source: the authors.

The annual data represented in Picture 6 shows predominance with $45.26 \%$ of days/year, in which it is not necessary to use bioclimatic strategies (Zone 1), because the comfort sensibility in the built environment is naturally achieved. Comparing to the study of Gobo et al. (2015) - even having been developed for urban scale, are similar, showing comfort temperatures for the summer period, and close ones for the periods of spring and autumn.

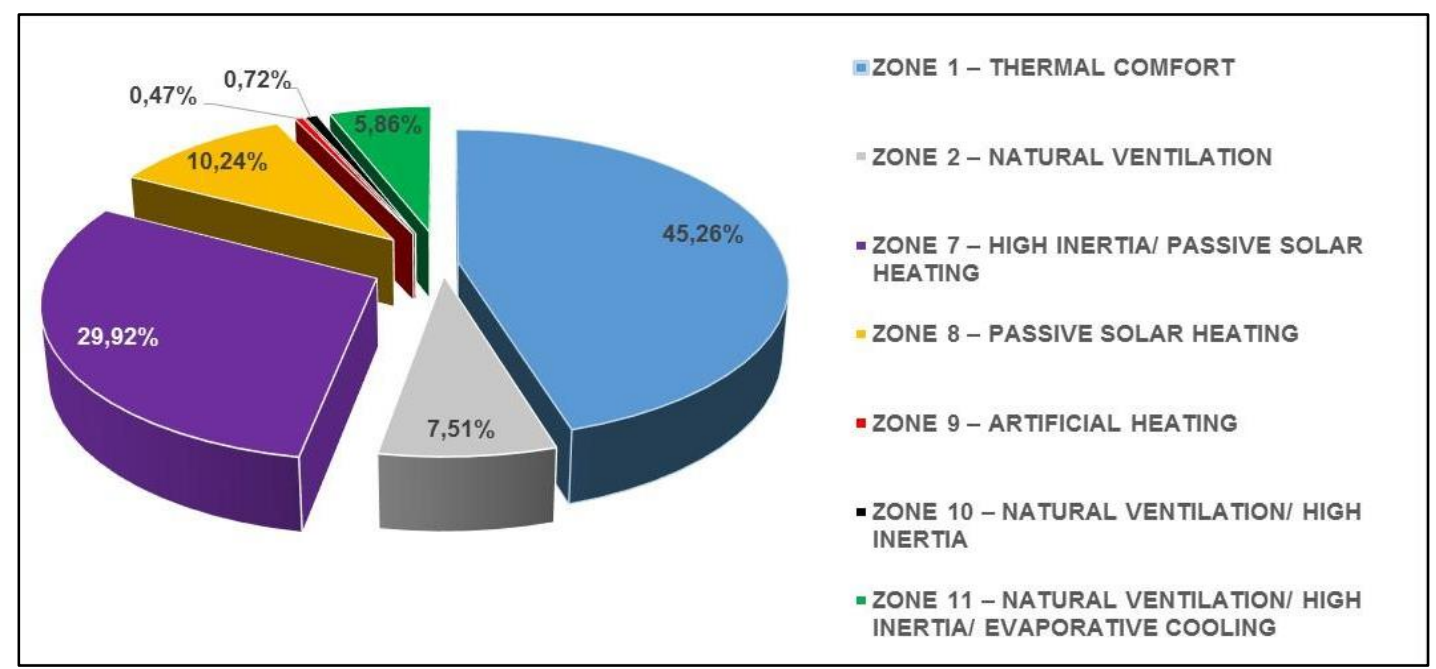

Picture 6 - Thermal Comfort Strategies for the city of Lajeado (Annual Average). 
The strategy of High Inertia ${ }^{3}$ Passive Solar Heating (Zone 7) can be used in $29.92 \%$ of days in separate or together, as described by Lamberts et al. (2013). Thus, this combination of strategies is fundamental for the period of days with lower temperatures, where the solar radiation can be used in abundance for heating the materials at the buildings openings with little protection.

The Passive Solar Heating strategy as a natural heating resource (Zone 8) appears with $10.24 \%$ of all days, rendering the utilization of the solar radiation through the buildings openings and transparencies aiming to achieve the comfort temperature for the indoor ambient. For this case, it can be considered the relative percentage of days at Zone 7 using this strategy, considerably the number of days/year. Doing so, the squares must be designed in such a way that the solar incidence will be received directly from the winter solstice radiation and kept protected during summer solstice (wall coverage, awning, solar protections, and so on).

Artificial Heating of the indoor ambient turned up as a strategy, which can be disregarded showing a low percentage of occurrences $(0.47 \%)$. Thus, it is confirmed that there is no necessity for the use of heating since investments for implementations are not worth due to low utilization. The sporadic use of elements, like fireplace or air conditioning equipment running the reverse cooling cycle (heating) can be envisaged.

Strategies of Zones 2, 10 and 11, achieve together approximately $15 \%$ of days/year (equivalent to the period of two months a year) with possibility to use the strategy of Natural Ventilation. Notably, these days have the tendency to occur in periods of summer. In these cases, the High Inertia strategy must be earmarked in projects for thermal isolation of the building, along with the alternative in appliance of diverse materials compositions. During hot days, the Evaporative Cooling strategy ${ }^{4}$ can be used, but only with a lesser percentage of relative air humidity, as not to increase the discomfort sensibility.

\subsection{BIOCLIMATIC CHART FOR LAJEADO/RS, FROM AVERAGE MAXIMUM AND ABSOLUTE MINIMUM TEMPERATURES.}

Analyzing the second bioclimatic developed based on maximum average and minimum absolute monthly temperatures, the predominance of the strategies for zones 1, 2, 7, 8, 10 and 11, previously analyzed, are followed. However, as shown in Figure 7 , there is an expansion of the activities of bioclimatic strategy of Zone 9 (Artificial Heating), and the need for application of bioclimatic strategies to zones 4 and 12, High Thermal Inertia for Cooling, and High Inertia/ Evaporative Cooling.

\footnotetext{
3 The High Inert strategy can be utilized for heating and cooling. In the periods of winter the materials can capture the heat during the day and liberates it gradually in the cooler period, helping on heating of the indoor ambient. In the period of summer, the buildings openings must be protected and the materials must be kept shaded to lessen the temperature of the indoor ambient (LAMBERTS et al. ; 2013).

${ }^{4}$ Bioclimatic strategy, in which can be made use of the wind currents to cool water droplets, which can be put into sprayed air suspension (aspersion). This strategy is an adequate solution for periods with very low relative air humidity and temperatures lower than $27^{\circ} \mathrm{C}$ (LAMBERTS et al.; 2013).
} 


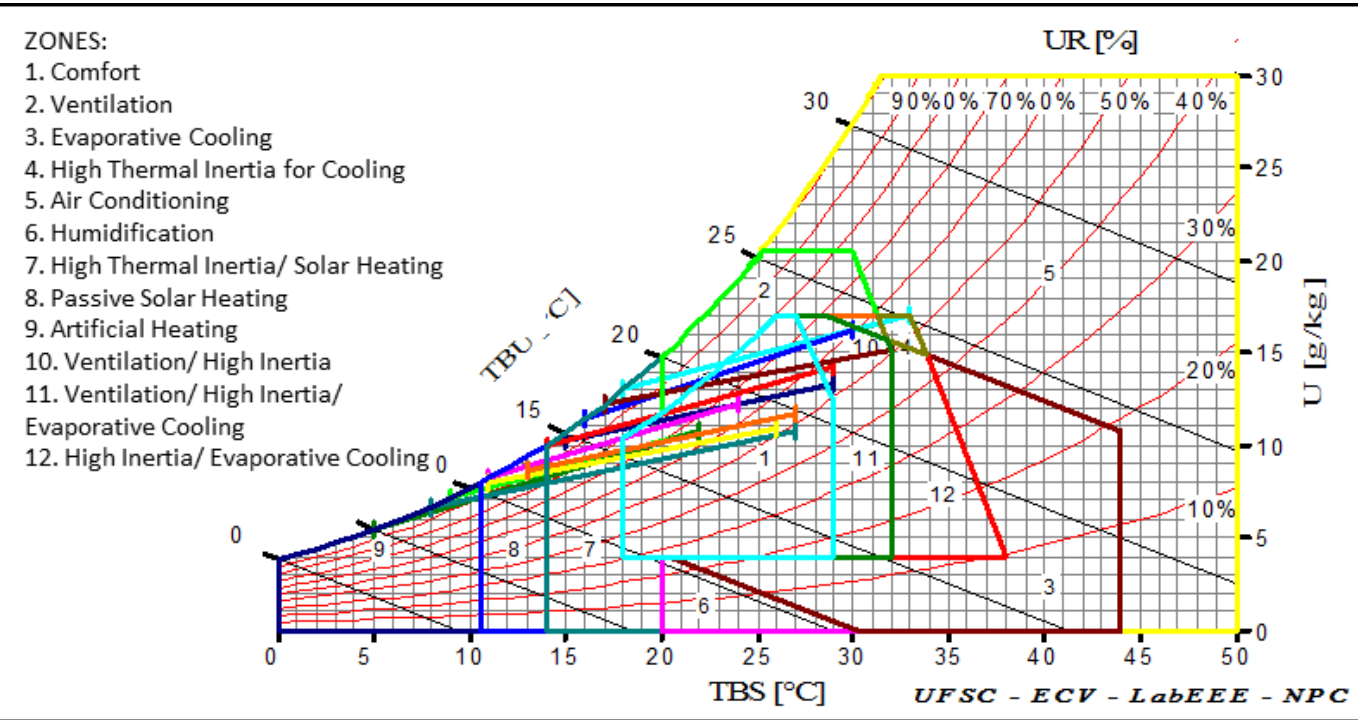

Picture 7 - Bioclimatic Chart for Lajeado/RS (Average Absolute Temperatures).

Analyzing the information, the Table 4 was developed based on the aggregation of data in amount of days (percentage) for each month. There is a significant expansion of recommendation for the use of Artificial Heating strategies (Zone 9), in order to suit buildings environments during more intense winter periods, corresponding to the months of June, July and August. For the months of January and February, it is recommended the use of the strategy of High Thermal Inertia for Cooling (Zone 4), adapting the materiality and the heat gain by excess solar radiation.

The strategy of High Inertia/Evaporative Cooling (Zone 12) is recommended for the month of December, but with a percentage of $0.39 \%$ with possibility of use. As submitted previously, the strategy of Evaporative Cooling would not be suitable for use in the region, due to the high percentage of relative humidity.

Table 4 - Bioclimatic Monthyl Estrategies for the City of Lajeado/RS (Average Absolute Temperatures).

\begin{tabular}{|c|c|c|c|c|c|c|c|c|c|}
\hline & ZONE 1 & ZONE 2 & ZONE 4 & ZONE 7 & ZONE 8 & ZONE 9 & $\begin{array}{c}\text { ZONE } \\
10\end{array}$ & $\begin{array}{c}\text { ZONE } \\
11\end{array}$ & $\begin{array}{c}\text { ZONE } \\
12\end{array}$ \\
\hline JAN & $31.53 \%$ & $20.23 \%$ & $9.56 \%$ & $13.34 \%$ & & & $4.16 \%$ & $21.18 \%$ & \\
\hline FEB & $29.34 \%$ & $21.71 \%$ & $10.37 \%$ & $13.34 \%$ & & & $6.82 \%$ & $18.41 \%$ & \\
\hline MAR & $38.75 \%$ & $16.43 \%$ & & $28.58 \%$ & & & & $16.24 \%$ & \\
\hline APR & $68.29 \%$ & & & $29.68 \%$ & & & & $2.03 \%$ & \\
\hline MAY & $46.07 \%$ & & & $30.86 \%$ & $23.08 \%$ & & & & \\
\hline JUN & $30.77 \%$ & & & $30.77 \%$ & $26.92 \%$ & $11.54 \%$ & & & \\
\hline JUL & $23.53 \%$ & & & $23.53 \%$ & $20.58 \%$ & $32.36 \%$ & & & \\
\hline AUG & $47.37 \%$ & & & $21.05 \%$ & $18.42 \%$ & $13.16 \%$ & & & \\
\hline SEP & $53.33 \%$ & & & $26.67 \%$ & $20.00 \%$ & & & & \\
\hline OCT & $64.29 \%$ & & & $28.57 \%$ & $7.15 \%$ & & & & \\
\hline NOV & $56.16 \%$ & & & $39.38 \%$ & & & & $4.46 \%$ & \\
\hline DEC & $42.05 \%$ & $12.32 \%$ & & $20.00 \%$ & & & & $25.25 \%$ & $0.39 \%$ \\
\hline
\end{tabular}


OBS.: Zone 1 - Thermal Comfort; Zone 2 - Natural Ventilation; Zone 4 - High Thermal Inertia for Cooling; Zone 7 - High Thermal Inertia / Passive Solar Heating; Zone 8 - Passive Solar Heating; Zone 9 - Artificial Heating; Zone 10 - Natural Ventilation / High Inertia; Zone 11 - Natural Ventilation / High Inertia / Evaporative Cooling; Zone 12 - High Inertia / Evaporative Cooling.

Source: the authors.

Analyzing the data for the year, as shown in Picture 8, the predominance of the strategies presented in the Bioclimatic Chart generated by the monthly averages (Picture 6) is clear. The percentage presented in Zone $4(1.63 \%)$ shows considerable value and can worked along with the strategies of the Zones 7, 10 and 11 . The use of Zone 9 strategy appears very small $(0.03 \%)$, recommending that it should work along with the strategies of the Zones 10 and 11.

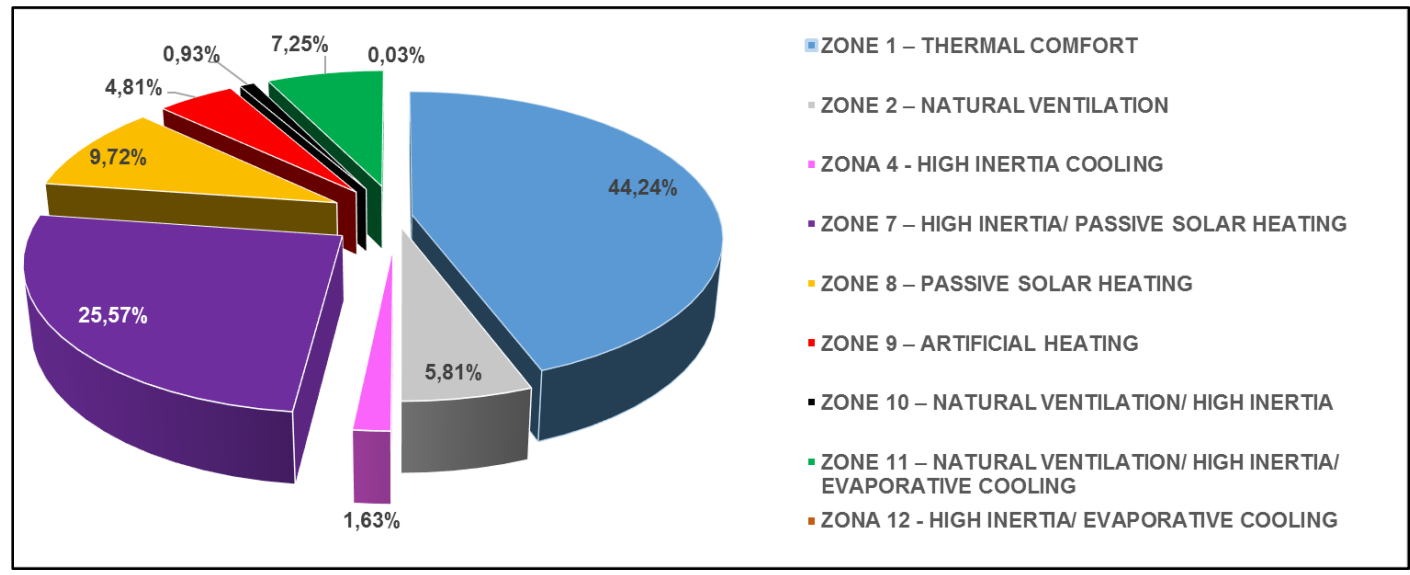

Picture 8 - Thermal Comfort Strategies for the City of Lajeado/RS (Average Absolute Temperatures).

Thus, closing the analysis of the information presented in Pictures 6 and 8 , the percentage data has been inserted in the Software BioEstat in order to develop statistical analysis by applying the Variance Analysis Method for one criterion. In conclusion, the analysis showed no significant variation, highlighting the of the results validation from the use of Monthly Averages to the Absolute Averages analyzed results.

\subsection{NATURAL VENTILATION STRATEGY AND WIND PREDOMINANCE FOR THE CITY OF LAJEADO/RS}

According to Lamberts et al. (2013), the natural ventilation strategy is one of the most important for Brazil since it can be used as an ideal strategy in all bioclimatic zones of territories, showing a temperature variation between $20^{\circ} \mathrm{C}$ and $32^{\circ} \mathrm{C}$, and relative humidity of $15 \%$ a $75 \%$. The calculated climatic averages in this study confirm the possibility of using this strategy for the city of Lajeado in October and February, coincidently with periods in spring and summer, as an ideal alternative to improve the energy performance of buildings.

It should be emphasized that the Natural Ventilation strategy (Zone 2), is important due to the high levels of relative air humidity. The high levels occur, probably, by the presence of the two rivers (Foqueta and Taquari) by the 
municipality, with large volume of water. The continentality characteristic and the difference in elevation from the Lajeado region to the nearby region to the North (Northern Rio-Grandense Plateu), can be a determining factor for the retention and increase of this levels, locally.

Thus, based on available data from the $\mathrm{CIH}$, a new wind rose for the city of Lajeado was developed, qualifying and classifying the data respectively to climatic seasons. Comparing to the studies of Tomasini (2011) and the Wind Atlas of the state Rio Grande do Sul (2014), the average data plotted to the wind rose show a general predominance for the directions SE and NO.

However, the qualification of the data regarding previous studies shows desirable abilities to determine the protection type or a more adequate opening for a determined orientation of the building facade, with respect to the climatic season, and thus enabling the development of techniques to minimize quantities of heat in summer or maintaining the indoor temperature in winter (maintenance of heat in environments); in summary holding the comfort temperature for the constructed building.

In Picture 9 are shown the periods of summer and spring with predominance to the orientations inclined to SE with a good average wind speed (Picture 10) in spring, which can help significantly to the bioclimatic strategy of natural ventilation.

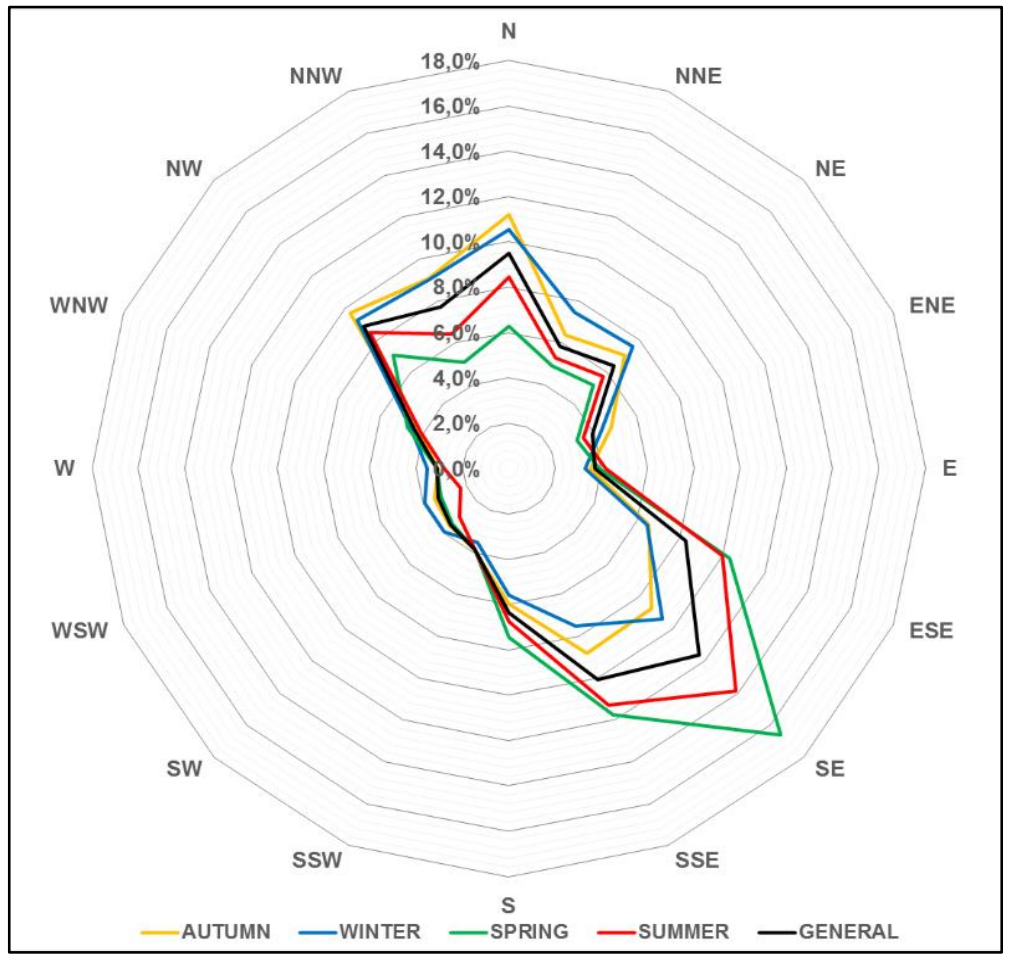

Picture 9 - Predominance Wind (\%) for the city of Lajeado (Period 2004-2015).

In winter periods there is wind predominance for directions $\mathrm{N}, \mathrm{NW}$ and $\mathrm{SE}$, maintaining the average in hot periods, but with a more regular distribution (Picture 9). For the days in autumn where the winds speed is more clement than 
in winter (Picture 10) with a direction predominant from $\mathrm{N}$, buildings have to be protected for not losing their stored heat.

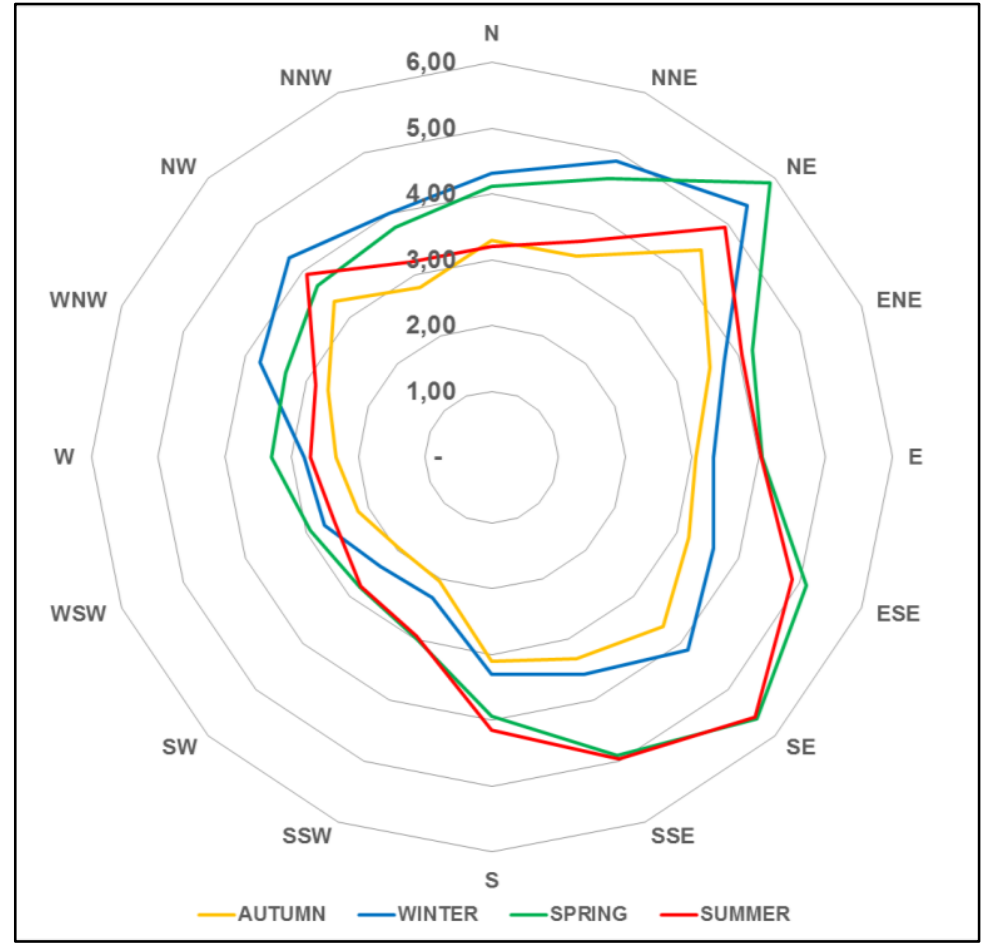

Figure 10 - Average Wind Speed (km/h) for the city of Lajeado (2004-2015).

The analysis of wind speed and direction is fundamental due the quantity of days where the bioclimatic strategy of natural ventilation can be used for the region. Importantly, for a successful realization this strategy can be attended beside a higher amount of windows in the buildings facades or cross ventilation, with a great variety of architectonic tools, among other alternatives, evaluating the chimney effect system, static aspirators or geothermic ventilation.

\section{CONCLUSION}

The presented results of the climatic analyses highlight the importance of the developed study for the city of Lajeado. It is also important to note that the applied method (analysis of climatic data) can also be used to other regions. The presented bioclimatic strategies destined for application in architectonic projects, meet the local demand for occurrence of a cultural rearrangement in construction and answer the comfort questions of constructed ambient and energy efficiency.

The high indices regarding the natural ventilation strategy presented in this study offer a huge opportunity to assess new constructive elements, which differ from conventional standards, for a better use of this natural resource. The Thermal Inertia strategy needs to be rethought, abandoning outdated techniques and working out new ones or combinations of construction materials. 
At this point, the materials have to be related to European standards, to achieve good energy efficiency indices for buildings.

Pointing out the analysis of the bioclimatic chart, the low frequency of these days in which the use of Air Conditioning (Zone 5) or Artificial Heating (Zone 9) are indicated, bearing in mind that these capabilities are typically widely used. Additionally, the necessity for a special working method for thermal isolation of new and preexisting buildings is highlighted for the best customization of human beings to the built environment, energy efficiency and the projectural rationality, based on local climatic characteristics and data.

The study can be complemented by the addition of indices related to geographical attributes of sites that can be studied, such as precipitation, land use, continentality and maritime dimension, which can influence directly on the characteristics of thermal comfort and strategies to be used in building projects.

\section{REFERENCES}

ASCENSO, Rita. Nearly zero energy buildings - O que vai mudar com os NZEB? Edifícios e Energia. Algés, Portugal. 2016. Dsiponível em: <http://www.edificioseenergia.pt/pt/a-revista/artigo/tema-de-capa-1>. Accessed on Oct 20. 2016.

Associação Brasileira de Normas Técnicas. NBR 15220-3 - Desempenho Térmico de Edificações - Parte 3. Rio de Janeiro, 2005.

ATLAS eólico. Porto Alegre: Secretaria de desenvolvimento e promoção do investimento, 2014.

AYRES, Manuel. BioEstat, versão 5.3. Universidade Federal do Pará (UFP), Belém. 2007.

BATIZ, Eduardo Concepción; GOEDERT, Jean; MORSCH, Junir Junior; JUNIOR, Pedro Kasmirski; VENSKE, Rafael. Avaliação do conforto térmico no aprendizado: estudo de caso sobre influência na atenção e memória. Produção, São Paulo, v.19, n.3, p.477-488, 2009.

BHANDARI, Mahabir; SHRESTHA, Som; NEW, Joshua. Evaluation of weather datasets for building energy simulation. Energy and Buildings. v. 49, june, p. 109-118. 2012.

BRITO, L.A.P.F.; CABRAL, S. Análise bioclimática do Município de Caraguatatuba de São Paulo de 1998 a 2006. Revista Tecno-lógica. Santa Cruz do Sul. v. 12, n. 1, p. 1-6. 2008.

Directiva 2002/91/CE do Parlamento Europeu e do Conselho, Relativa ao Desempenho Energético dos Edifícios, de 16 dez. 2002. Disponível em: $<$ http://eur-lex.europa.eu/legal-

content/PT/TXT/PDF/?uri=CELEX:32002L0091\&from=ES>. Accessed on Nov 12. 2016.

GIVONI, B. Man, climate and architecture. Amsterdam: Elseveir Publishing Company Limited. (Architectural science series.), 1969

. Confort, Climate Analysis and Building Design Guidelines. Energy and Buildings, v.18, n. 1, p. 11-23, 1992. 
GRIGOLETTI, Giane de Campos; FLORES, Michelle Gomes; SANTOS, Joaquim Cesar Pizzutti dos. Tratamento de dados climáticos de Santa Maria, RS, para análise de desempenho térmico de edificações. Ambiente Construído, Porto Alegre, v. 16, n. 1, p. 123-141, jan. 2016.

GOBO, João P.A.; GALVANI, Emerson; WOLLMANN, Cassio Arthur; CELUPPI, Maria Cristina. Estudo de zoneamento do conforto térmico humano para o Rio Grande do Sul: A inserção de anos-padrão como proposta metodológica. Ciência e Natura. Santa Maria, v. 37, n. 4, p. 451-470. set./dez. 2015.

IBGE. Censo Demográfico 2010. Brasília: IBGE, 2010. Disponível em: <http://cidades.ibge.gov.br/painel/historico.php?lang $=\&$ codmun $=431140>$. Accessed on Oct 28. 2016.

JOURDA, Françoeise-Hélène. Pequeno Manual do Projeto Sustentável. Barcelona: Editorial Gustavo Gili, 2012.

LABEEE. Analysis Bio, versão 2.2. Laboratório de Eficiência Energética em Edificações - UFSC, 2010. Disponível em: <http://www.labeee.ufsc.br>.

LAMBERTS, Roberto; DUTRA, Luciano; PEREIRA, Fernando Oscar Ruttkay. Eficiência energética na arquitetura. Rio de Janeiro: Eletrobras, 2013.

LAMBERTS, R.; XAVIER, A. A. P. Conforto térmico em ambientes internos. Florianópolis: Laboratório de Eficiência Energética em Edificações, 2003. (Material didático para disciplina conforto térmico). Disponível em: <http://teses.eps.ufsc.br/Resumo.asp?1250>. Accessed on Oct 04. 2016.

LARASATI ZR, Dewi; MOCHTAR, Sahid. Application of bioclimatic parameter as sustainability approach on multi-story building design in tropical área. Procedia Environmental Sciences. Japan. V.17, p. 822-830. 2013.

MUNIZ, Francisco G.L.; CARACRISTI, Isorlanda. Urbanização, Conforto Térmico e Análise Sazonal Microclimática da Cidade de Sobral(Ce). Revista da Casa da Geografia de Sobral. Sobral, v. 17, n. 1, p. 4-17. Mar. 2015.

ONU-Organização das Nações Unidas. Acordo de Paris para o clima entra em vigor; ONU pede mais esforços na redução de emissões. 2016. Link: $<$ https://nacoesunidas.org/acordo-de-paris-para-o-clima-entra-em-vigor-onupede-mais-esforcos-na-reducao-de-emissoes/>. Accessed on Nov 07. 2016.

Prefeitura Municipal de Lajeado (PML). Link: <http://www.lajeado.rs.gov.br/?titulo=Lajeado\&template=conteudo\&categoria $=$ 931\&codigoCategoria $=931$ \&idConteudo $=2988 \&$ tipoConteudo $=$ INCLUDE_MOSTR A_CONTEUDO>. Accessed on Oct 25. 2016.

ROAF, Sue; CRICHTON, David; NICOL, Fergus. A adaptação de edificações e cidades às mudanças climáticas: um guia de sobrevivência para o século XXI. Porto Alegre: Bookman, 2009.

SPINELLI, R.; ALVES, A.; KONRAD, O. Cidade e Edificações: A busca por um novo modelo. Destaques Acadêmicos. Lajeado, v. 5, n. 4, p.173-186. dez. 2013.

SOFFIATI, Arthur. Algumas palavras sobre uma teoria da eco-história. Desenvolvimento e Meio Ambiente. Paraná. n. 18, p. 13-26. jul./dez. 2008.

TOMASINI, Juliana. Padrão de variabilidade do vento à superfície, em Lajeado, Rio Grande do Sul, Brasil: implicações ambientais. 2011. 58 f. f. Monografia 
(Bacharel em Engenharia ambiental) - Curso de Engenharia ambiental, Centro Universitário Univates, Lajeado, 2011. 